\title{
WATER QUALITY ASSESSMENT OF DRIGH LAKE, A WILDLIFE SANCTUARY AND RAMSAR SITE IN DISTRICT LARKANA SINDH, PAKISTAN
}

\author{
Sahibzado Farmanullah Rashidi, Kalsoom Shaikh*, Waheed Shabrani, Khalid Saifullah Rajput, Ghulam \\ Sarwar Gachal, Abdul Rehman Shaikh, Hira Lakho, Hissam Uddin Bhatti, Taha Butto, Aisha Memon \\ "University of Sindh, Department of Zoology, Jamshoro, Pakistan; \\ *Corresponding Author Kalsoom Shaikh, e-mail: kalsoom.shaikh@usindh.edu.pk;
}

Received February 2021; Accepted March 2021; Published April 2021;

DOI: https://doi.org/10.31407/ijees11.221

\begin{abstract}
Our study aimed to assess the selected physico-chemical parameters to examine water quality of Drigh Lake as huge diversity of fishes, amphibians and birds are dependent on this lake. The water samples were collected from six locations of Drigh lake to investigate the seasonal variations in physic-chemical parameters and to identify the potential contamination sources responsible for water pollution at the lake. The physic-chemical parameters analyzed were $\mathrm{pH}, \mathrm{EC}$, TDS, T. Hardness, T. Alkalinity, $\mathrm{Cl}, \mathrm{SO}_{4}, \mathrm{PO}_{4}, \mathrm{NO}_{2}$ and $\mathrm{NO}_{3}$. The mean concentration of all the parameters observed were $\mathrm{pH}(7.8)$, electric conductivity $(2286.62 \mathrm{mS} / \mathrm{cm})$, total dissolved solids $(1552.58$ $\mathrm{mg} / \mathrm{L})$, total hardness $(356.78 \mathrm{mg} / \mathrm{L})$, total alkalinity $(302.59 \mathrm{mg} / \mathrm{L})$, chloride $(313.92 \mathrm{mg} / \mathrm{L})$, sulphate $(389.50$ $\mathrm{mg} / \mathrm{L})$, phosphate $(398.59 \mathrm{mg} / \mathrm{L})$, nitrite $(3.46 \mathrm{mg} / \mathrm{L})$ and nitrate $(5.70 \mathrm{mg} / \mathrm{L})$. The results of all the physico-chemical parameters observed were above the guideline values of WHO and EPA which indicates the quality of water at Drigh lake is not suitable for survival of aquatic life.
\end{abstract}

Keywords: Drigh Lake, Water quality, Physico-chemical parameters, Sindh. 